\title{
Prebiotic supplementation effect on Escherichia coli and Salmonella species associated with experimentally induced intestinal coccidiosis in rabbits
}

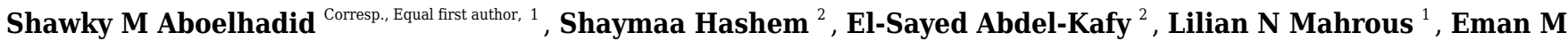 \\ Fargahly $^{2}$, Abdel-Azeem Abdel-Baki ${ }^{3}$, Saleh AlQuraishy ${ }^{4}$, Asmaa Kamel ${ }^{\text {Equal first author, } 1}$ \\ 1 Parasitology Department, Faculty of Veterinary Medicine, Beni-Suef University, Beni-Suef, Egypt \\ 2 Animal Production Research Institute, Agricultural Research Center, Dokki, Giza, Egypt \\ ${ }^{3}$ Zoology Department, Faculty of Science, Beni-Suef University, Beni-Suef, Egypt \\ ${ }^{4}$ Zoology Department, , College of Science, King Saud University, Riadh, Saudi Arabia \\ Corresponding Author: Shawky M Aboelhadid \\ Email address: shawky.abohadid@vet.bsu.edu.eg
}

Background:Coccidian infection may enhance the proliferation of gut Enterobacteriaceae. Bacterial infections in rabbits can negatively affect the body condition and cause high mortality, especially at young ages. Therefore, the effect of prebiotic supplementation on the presence ofEscherichia coliandSalmonellaspecies in rabbits experimentally infected with intestinal coccidiosis was investigated. Methods:Thirty male rabbits aged 35-40 days were divided into 3 equal groups. These groups were; prebiotic supplemented (PS), positive control (PC), and negative control (NC) groups. The prebiotic group was supplemented with $2 \mathrm{~g} / \mathrm{L}$ of Bio-Mos ${ }^{\circledR}$ until the end of the experiment. At day ten post prebiotic supplementation; the PS and PC groups were inoculated orally with

$5.0 \times 10^{4}$ sporulated oocysts of mixed species of rabbitEimeria. The daily fecal examination was carried out from the day 4 post-infection (PI) until the day 8 PI. At day 5 and day $8 \mathrm{PI}$, 5 rabbits from each group (PS, PC, and NC) were humanely slaughtered and parts of intestinal tissue were collected for microbiological analysis. Results:There was a significant decrease $(P \leq 0.05)$ in the oocyst count in the PS group $\left(25.12 \times 10^{4} \pm 10.36\right)$ when compared with the PC group $\left(43.43 \times 10^{4} \pm 11.52\right)$ and this decrease was continued till the end of the experiment. Eleven $E$. coli isolates were detected in the collected samples with an overall prevalence of $24.4 \%$. The highest prevalence of $E$. coli was in the PC group (13.33\%) while the lowest one was in the PS group (4.44\%). Meanwhile, four Salmonella serovars were isolated with an overall prevalence of $8.89 \%$. The NC group showed one serovar $(2.22 \%)$ and PC revealed three serovars $(6.67 \%)$ while the prebiotic supplemented group didn't show any salmonella isolate. Of $E$. coli isolates, five isolates $(078,0125,0152,0115$ and 0168$)$ showed high resistance to florfenicol and neomycin Peer] reviewing PDF | (2020:07:51187:2:1:NEW 7 Dec 2020) 
(100\%). Also, of salmonella serovars, thee serovars (Salmonella entrica subsp. enterica serovar Macclesfield, Salmonella entrica Subsp. enterica serovar canada and Salmonella entrica Subsp. enterica serovar Kisangani) showed high resistance to sulphamazole, amoxicillin and flumequin (75\%) while it was sensitive to levofloxacin and ciprofloxacine (75\%). The bacterial colony in this study was the same results at days 5 and $8 \mathrm{PI}$.

Conclusion:The use of prebiotic as prophylaxis in this experiment significantly reduced the prevalence of $E$. coli and salmonella associated with the intestinal coccidiosis in rabbits. 
1 Prebiotic supplementation effect on Escherichia coli and Salmonella species associated with

2

3

4

5

$6{ }^{1}$ Parasitology Department, Faculty of Veterinary Medicine, Beni-Suef University, Beni-Suef, Egypt;

$7 \quad{ }^{2}$ Animal Production Research Institute, Agricultural Research Center, Dokki, Giza, Egypt

$8{ }^{3}$ Zoology Department, Faculty of Science, Beni-Suef University, Beni-Suef, Egypt;

$9{ }^{4}$ Zoology Department, College of Science, King Saud University, Saudi Arabia

\section{experimentally induced intestinal coccidiosis in rabbits}

\author{
Shawky M Aboelhadid ${ }^{1}$, Shaymaa Hashem² ${ }^{2}$ El-Sayed Abdel-Kafy ${ }^{2}$, Lilian N Mahrous ${ }^{1}$, Eman M \\ Farghly $^{2}$, Abdel-Azeem Abdel-Baki ${ }^{3}$, Saleh AlQuraishy ${ }^{4}$, Asmaa Kamel ${ }^{1}$
}

Correspondence to: Shawky M Aboelhadid, E.mail: drshawky2001@yahoo.com;

\section{Abstract}

Background: Coccidian infection may enhance the proliferation of gut Enterobacteriaceae. Bacterial infections in rabbits can negatively affect the body condition and cause high mortality, especially at young ages. Therefore, the effect of prebiotic supplementation on the presence of Escherichia coli and Salmonella species in rabbits experimentally infected with intestinal coccidiosis was investigated.

Methods: Thirty male rabbits aged 35-40 days were divided into 3 equal groups. These groups were; prebiotic supplemented (PS), positive control (PC), and negative control (NC) groups. The prebiotic group was supplemented with $2 \mathrm{~g} / \mathrm{L}$ of Bio-Mos ${ }^{\circledR}$ until the end of the experiment. At day ten post prebiotic supplementation; the PS and PC groups were inoculated orally with $5.0 \times 10^{4}$ sporulated oocysts of mixed species of rabbit Eimeria. The daily fecal examination was carried out from the day 4 post-infection (PI) until the day 8 PI. At day 5 and day 8 PI, 5 rabbits from each group (PS, PC, and NC) were humanely slaughtered and parts of intestinal tissue were collected for microbiological analysis.

Peer) reviewing PDF | (2020:07:51187:2:1:NEW 7 Dec 2020) 
27 Results: There was a significant decrease $(P \leq 0.05)$ in the oocyst count in the PS group $(25.12 \mathrm{x}$

$\left.2810^{4} \pm 10.36\right)$ when compared with the PC group $\left(43.43 \times 10^{4} \pm 11.52\right)$ and this decrease was

29 continued till the end of the experiment. Eleven E. coli isolates were detected in the collected

30 samples with an overall prevalence of $24.4 \%$. The highest prevalence of E. coli was in the PC

31 group (13.33\%) while the lowest one was in the PS group (4.44\%). Meanwhile,

32 four Salmonella serovars were isolated with an overall prevalence of $8.89 \%$. The NC group

33 showed one serovar (2.22\%) and PC revealed three serovars (6.67\%) while the prebiotic

34 supplemented group didn't show any salmonella isolate. Of E. coli isolates, five isolates (O78,

$35 \mathrm{O} 125, \mathrm{O} 152, \mathrm{O} 115$ and $\mathrm{O} 168)$ showed high resistance to florfenicol and neomycin (100\%). Also,

36 of salmonella serovars, thee serovars (Salmonella entrica subsp. entericaserovar

37 Macclesfield, Salmonella entrica Subsp. enterica serovar canada and Salmonella entrica Subsp.

38 enterica serovar Kisangani) showed high resistance to sulphamazole, amoxicillin and flumequin

$39(75 \%)$ while it was sensitive to levofloxacin and ciprofloxacine (75\%). The bacterial colony in

40 this study was the same results at days 5 and 8 PI.

41 Conclusion: The use of prebiotic as prophylaxis in this experiment significantly reduced the

42 prevalence of E. coli and salmonella associated with the intestinal coccidiosis in rabbits.

43 Keywords: Rabbits; Coccidiosis; Prebiotic; Salmonella species, Escherichia coli; antibiotic

44 resistance.

45 Introduction

46 Nowadays, the antibiotic resistance has emerged as the greatest challenge in the animal

47 production and human health. The extensive use of antibiotics as growth promoters for livestock

48 is the major cause of antibiotic resistance (WHO 2000; Millman et al. 2013; Mitchell et al. 2013).

49 Rabbit is a good source of animal protein to fill the gap of the red meat shortage in some parts of

50 the world, and sometimes reared for fur production as well as for medical and biological purposes

51 (Dalle and Szendro 2011; Aboelhadid et al. 2019). Rabbit coccidiosis is caused by apicomplexan 
52 parasites of the genus Eimeria (Pakandl 2009). Coccidiosis is mainly occurring in young rabbits

53 of one to three months' age especially after weaning. The clinical signs of coccidiosis are:

54 reduced appetite, enteritis, diarrhea, and in severe cases infection may result in death (El-Shahawi

55 et al. 2011). There are two types of rabbit coccidiosis; intestinal coccidiosis which caused by

56 several species including E. intestinalis, E. perforans, E. magna, E. media, and E. irresidua and,

57 hepatic coccidiosis which caused by only E. steidae (Pakandl 2008). Rashwan and Marai (2000)

58 postulated that the coccidian infection may enhance the proliferation of the gut

59 Enterobacteriaceae. Bacterial infections in rabbits can negatively affect the body condition and

60 cause high mortality, especially in young ages (Zahraei et al. 2009). Infections with

61 Enterobacteriaceae are more challenging to treat, because few, and in some cases no,

62 antimicrobials remain effective against them, because of their extensive resistance patterns and in

63 addition the antibiotic chemical residue in animal products may create problems for human

64 wellbeing (Smith et al. 2002).

Salmonella species were reported to infect rabbits in several rabbitries and the infection

66 can lead to severely diseased condition (Agnoletti et al. 1999; Zahraei et al. 2009, Saco et al.

67 2012, Borelli et al. 2011).

68 Escherichia coli is an important cause of diarrhea in both animals and humans (Nguyen et

al. 2006; Garcia et al. 2010). Also, it was reported to cause morbidity and mortality in large

70 laboratory rabbits (Swennes et al. 2012, 2014). Escherichia coli was known as a reason for

71 diarrhea in new born of New Zealand rabbits (Camarda et al. 2012, Hamed et al. 2013). Prescott

72 (1978) found that the outbreak of severe diarrhea and death in young rabbits was associated with

73 non-enterotoxigenic Escherichia coli (O153).

Recently, the prebiotics were defined as "a substrate that is selectively utilized by host

75 microorganisms conferring a health benefit" (Gibson et al. 2017). The prebiotics administration

76 could regulate specific gastrointestinal tract microorganisms to modify the microbiome (Gibson 
77 and Roberfroid 1995). Abdelhady and El-Abasy (2015) found that the prebiotic and probiotic as

78 dietary supplementation reduced the mortality rate and improved the adverse clinical signs of

79 Pasterella multocida in experimentally infected rabbits. Tzortzis et al. (2005) realized that the

80 oligosaccharides greatly inhibited the adhesion of E. coli and Salmonella to HT29 cells. Also,

81 Yusrizal and Chen (2003) revealed that fructans supplementation induced an increase in

82 Lactobacillus bacteria and a reduction in Salmonella in the broiler chickens. Moreover, it was

83 noticed that prebiotics intake reduced the establishment of Salmonella in the course of hen

84 molting (Donalson et al. 2008). Spring et al. (2015) demonstrated that Bio-Mos ${ }^{\circledR}$, which has

85 been used in the animal husbandry industry, plays a crucial role in animal nutrition and

86 production. It was extracted from a selected strain of Saccharomyces cerevisiae yeast. Bio-Mos is

87 inserted into animal diets to support overall animal performance and rapid growth. It is supported

88 by over 734 trials and 114 peer-reviewed publications. There is considerable evidence now that

89 Bio-Mos is among the best alternatives to antibiotic and growth promotants (Ferket et al. 2002).

90 The present study was therefore conducted to explore the effect of a prebiotic supplement

91 as a prophylaxis on the presence of E. coli and Salmonella species in rabbits with experimentally

92 induced intestinal coccidiosis.

93 Materials and methods

94 This experiment was conducted under the roles of the ethical standards approved by Faculty

95 of Veterinary Medicine, Beni-Suef University, Egypt and its specific approval number was 96 (BSUV-39/2019).

97 1. Rabbits

98 A total of thirty male rabbits recently weaned (V-Line breed) aged 35-40 days with an 99 average weighed of one $\mathrm{kg}$, were used in the current work. The experiment was carried out in a 100 rabbit farm in a station of animal production in Sedes station for agriculture research, Beni-Suef, 101 Egypt. The rabbits were housed in metal cages where a single rabbit was located in a separate 
102

103

104

105

106

107

108

109

110

111

112

113

114

115

116

117

cage. Rabbits fed on anticoccidial drugs free commercial pelleted diet (18\% crude protein, 14\% crude fiber, $2500 \mathrm{k}$ calories digestible energy $/ \mathrm{kg}, 1 \%$ calcium and $0.5 \%$ phosphorus). The water and feed were ad libitum. The fecal examination was done daily before induction of the infection to be sure that the rabbits were free from any other parasites.

\section{Experimental design of prebiotic prophylaxis efficacy}

The thirty rabbits were randomly divided into 3 groups with10 rabbits in each group. These groups were as following: Prebiotic supplemented group (PS), positive control group (PC), and negative control group (NC). The prebiotic group was supplemented with $2 \mathrm{~g} / \mathrm{L}$ of prebiotic (Bio$\operatorname{Mos}{ }^{\circledR}$, ALLTECH, INC.CO. USA) derived from a selected strain of Saccharomyces cerevisiae yeast in the drinking water for ten days while the other groups remained as they were. At day ten post prebiotic supplementation; the PS and PC groups were orally inoculated with $5.0 \times 10^{4}$ sporulated oocysts of mixed Eimeria species including E. media, E. flvescens, E. intestinalis and E. magna for each rabbit. The supplementation of prebiotic in PS group continued till the day 8 post infection. Daily fecal examination and oocysts count were carried out from day 3 until day 8 post infection (PI). The oocyst count was done using McMaster chamber (Lillehoj and Ruff 1987). At the day 5 and the day 8 PI, 5 rabbits from each group at each period were humanely slaughtered. These days was selected based on a preliminary work in which the oocyst shedding started at day 5 PI and reached to its peak at day 8 PI as shown in the supplemented figure. Parts of the intestinal tissue were excised for microbiological analysis. These parts were labeled and kept in ice tank then rapidly transported to the laboratory for examination. The rabbits were handled and euthanized with least distressful to them. Cervical dislocation was done because they were not of heavy weight (Walsh et al. 2017). Death was verified by lack of breathing, stop palpable heartbeat and fixed dilated pupil.

\section{Bacteriological examination}


126 The intestinal tissue samples (jejunum, ileum, and cecum) were collected separately in sterile

127 manner for each point of microbial investigation at 5 and 8 days PI. Consequently, a total 45

128 samples representing 15 animals at the selected days, 5 animals from each group and three organs

129 (jejunum, ileum, and cecum) for each animal. These samples were subjected to microbiological 130 examination for the presence of Salmonella and E. coli. Two intestinal swabs were taken from

131 each part. The first swab was seeded onto MacConkey Agar (Difco) to isolate E. coli, and the 132 subsequent colonies were recognized using Enterokit B and identified according to Lee et al. 133 (2009). To isolate Salmonella, the second swab was processed according to Michael et al. (2003).

134 The produced colonies were confirmed according to the standard procedures suggested by Holt et 135 al. (1994), ISO 6579:2002 and Lee and Arp (1998). Salmonella isolates were serologically 136 identified referring to somatic $(\mathrm{O})$ and flagellar $(\mathrm{H})$ antigens by slide agglutination using 137 commercial antisera (Popof and Le Minor 2001).

\section{4. Antimicrobial susceptibility test}

139 The disk-diffusion method was applied to assess the antibiogram of the isolated microorganisms 140 (Cruickshank 1975, CLSI/NCCLS 2009) against a series of 12 antibiotic discs (Tetracycline, 141 Sulphamazole, Naldixic acid, Trimethoprim, Gentamycin, Levofloxacin, Florfenicol, 142 Amoxicillin, Flumequin, Ciprofloxacine, Amikacin, Neomycin) (Oxoid, Basingstoke, UK) 143 (Supplemented table 1).

\section{5. Statistics}

145 ANOVA tests and subsequent Duncan's multiple range tests were used to analysis of oocysts 146 counts in different groups. Results were expressed as means \pm SE. Probability of values less than $1470.05(\mathrm{p} \leq 0.05)$ was considered significant.

\section{Results}

149 1. Prebiotic prophylaxis effect on the oocyst count and prevalence of both $E$. coli and 150 Salmonella species at day 5 and day 8 post infection 
152 groups. Also, the OPG was significantly reduced in the PS group $\left(25.12 \times 10^{4} \pm 10.36\right)$ when 153 compared with the PC group $\left(43.43 \times 10^{4} \pm 11.52\right)$ (Table 1$)$. This significant $(\mathrm{p} \leq 0.05)$ decrease

154 in the oocyst count in the PS group continued till the end of the experiment (day 8 PI). Eleven $E$.

155 coli isolates were detected during the present study with overall prevalence of $24.4 \%$. These

156 eleven isolates were three serotypes in $\mathrm{NC}$ with prevalence of $6.66 \%$, six serotypes PC with

157 prevalence of $13.33 \%$ and two serotypes in PS with a prevalence of $4.44 \%$ (Table 2). The highest

158 prevalence of E. coli was in the PC group while the lowest one was in the PS group. Meanwhile,

159 four salmonella serovars were isolated with overall prevalence of $8.89 \%$. The NC group showed 160 only one serovars with a prevalence of $2.22 \%$ and the PC group revealed three serovars with a 161 prevalence of $6.67 \%$ while prebiotic supplemented group didn't show any salmonella isolates 162 (Table 2). The same results of E. coli and Salmonella prevalence were recorded at day 8 PI.

\section{The intestinal isolates $E$. coli}

Five E. coli isolates were recovered from the intestinal tissues and identified as: O78, O125, O152, O115 and O168. The most common isolates were O78 and O152 with prevalence of (27.27\%) and they were isolated from jejunum and ileum. While the least common one was O125 $(18.18 \%)$ which was isolated from ileum (Table 3). The isolates from the NC group were (O152, O152, O168), while the PC group had six serotypes (O168, O152, O125, O125, O78, O78). The PS group showed only two serotypes $(\mathrm{O} 78, \mathrm{O} 115)$. The antimicrobial sensitivity tests of E. coli serotypes showed high resistance to florfenicol and neomycin (100\%), tetracycline, naldixic acid,

171 trimethoprim and flumequin (81.81\%) (Table 4 \& Supplemented table 2).

\section{Prevalence of Salmonellae species recovered from intestinal tissue}


176 with prevalence of 50\% (Table 5). Salmonella serovars isolates according the organs of isolation

177 showed one Salmonella entrica subsp. entericaserovar Maccles isolated from caecum, one

178 Salmonella entrica subsp. enterica serovar Canada isolated from jejunum and two Salmonella

179 entrica subsp. enterica serovar Kisangani isolated from ileum (Table 5). The antimicrobial

180 sensitivity tests of the isolated Salmonella serovars showed higher resistance to sulfamazole,

181 amoxicillin and flumequin (75\%) while they were sensitive to levofloxacin and ciprofloxacine

182 (75\%) (Table 6 \& Supplemented table 3).

183 Discussion

184 The use of antibiotics as growth promoters in animals was banned by the European Union

185 Commission (European Union Commission 2005), and since then, prebiotics and probiotics were

186 actively investigated as safe natural alternatives to the antibiotics. Prebiotics were known to have

187 valuable effects on the improvement of the host immune system, productivity and performance in

188 addition to its bactericidal / bacteriostatic activities. The prebiotics were also used as growth

189 promoters in the form of feed additives to increase growth of chickens (Ashayerizadeh et al.

190 2009). It was found that coccidial infection in most cases was associated with secondary bacterial

191 and viral infections that may lead to mortality in infected host (Taylor et al. 2003, Kowalska et al.

192 2012).

193 Therefore, the present study was suggested to investigate the prevalence of bacterial

194 infection in rabbit intestines experimentally infected with coccidiosis and the effect of prebiotic

195 supplementation on it. In the prophylactic trial, the prevalence of E. coli was $6.66 .11 \%$ in the NC

196 group and $13.33 \%$ in the PC group while, it was $4.4 \%$ in the PS group. These findings were in

197 agreement with those of Jouany et al. (2008), Kimse (2009) and Michelland et al. (2010).

198 Prebiotics were proven to have positive effect on certain pathogens where they able to control

199 enteric diseases associated with E. coli (Kritas and Morrison 2005, Timmerman et al. 2005). In

200 this respect, Servin-Coccoiner (2003) found that the gram-positive bacterium Lactobacillus lactis 
201 produced hydrogen peroxide and reduced of the growth of Escherichia coli 0157:H7. In the

202 present study the isolated E. coli showed high resistance against neomycin, florfenicol, 203 flumequin, sulphamazole, trimethoprim, nalidixic acid and tetracycline while, they were sensitive 204 to ciprofloxacine and amikacin. These outcomes similar to those of Flickinger and Fahey 205 (2002), Zhao et al. (2018) and Makhol et al. (2011).

206 On the other hand, the prevalence of Salmonella was $2.22 \%$ in the NC group and $6.7 \%$ in the PC 207 group while it was not detected in the PS group. The presence of Salmonella species with 208 coccidiosis was previously reported by Arwaka et al. (1992). They suggested that the infection 209 with E. tenella leading to changes in the balance of competitive adherence of bacteria which 210 allowing more colonization of S. typhimurium and Clostridium perfringens. Salmonella isolates 211 reported in the present study showed high resistance to sulphamazole, florfenicol, amoxicillin, 212 flumequin and naldixic acid while it revealed high sensitivity to ciprofloxacine, levofloxacin and 213 gentamycin. Several previous studies have demonstrated antimicrobial sensitivity outcomes 214 similar to those reported in the present study (Kumar et al. 2009, Camarda et al. 2012, Kim et al. 215 2012, Albuquerque et al. 2014, Agrawal et al. 2016, Lamas et al. (2016).

The present study showed high prevalence of E. coli and Salmonella serovars in the PC 217 group that indicates a relation between the infection by the intestinal coccidiosis and the 218 proliferation of enterobacteriacae micro-organisms. This finding was supported by Szabóová et 219 al. (2012) as they observed significant decrease in the bacterial prevalence in association with 220 reduction in the Eimeria oocysts count in rabbits which were administered a dietary 221 supplementation of natural substances. In addition, El-Ashram et al. (2020) found that the 222 coccidiosis infection in post weaning rabbits mostly associated with E. coli and Salmonella 223 species.

224 In the present study, the used prebiotic reduced the prevalence of E. coli and Salmonella 225 species associated with experimentally induced coccidiosis in rabbits with reduction of the 
226 adverse effect of coccidiosis. This in agreement with the results of El-Ashram et al. (2019) as

227 they found that the prebiotic supplementation reduced the adverse effects of the intestinal 228 coccidiosis in rabbits. Interestingly, Salmonella species was absent in the PS group which may

229 reflect the ability of prebiotic to inhibit colonization of Salmonella. This finding supported by

230 Micciche et al. (2018) as they showed that prebiotic creates of an environment that and inhibit

231 Salmonella colonization and growth in chicken intestine. In addition, Tran et al. (2018) found that

232 a prebiotic supplementation can cause inhibition to Salmonella and E. coli infections in pigs.

233 Moreover, Girgis et al. (2020) realized that prebiotic (Actigen ${ }^{\circledR}$ a mannan-rich yeast cell wall-

234 derived preparation) supplementation diminished the prevalence of Salmonella enteritis in cecal

235 contents of layer chickens. Prebiotics are always used as feed additives to improve growth,

236 endorse beneficial gastrointestinal microbiota, and decrease pathogens. The prebiotics increase

237 short chain fatty acid (SCFA) production in the cecum which leading to pathogen reduction

238 (Micciche et al. 2018, Girgis et al. 2020). The prebiotics promote the overall health and well-

239 being of the bird through creation of an intestinal environment unfavorable for Salmonella

240 colonization (Micciche et al. 2018).

241 In conclusion, the using of prebiotic as prophylaxis in this study, significantly reduced the

242 prevalence of the E. coli and prevented the salmonella infection that associated with intestinal

243 coccidiosis in rabbits. In addition, it reduced the intestinal coccidiosis adverse effect from the

244 way of reduction of oocysts count.

245 Conflict of interest

246 None

247 Acknowledgements

248 This work was supported by Researcher supporting Project (RSP-2019/3), King Saud University.

249 References 
250 Abdelhady DH, El-Abasy MA (2015) Effect of Prebiotic and Probiotic on Growth, Immuno-

251 hematological responses and Biochemical Parameters of infected rabbits with Pasteurella 252 multocida. Benha Vet Med J 28 (2):40-51

253 Aboelhadid SM, El-Ashram S, Hassan KM, Arafa WM, Darwish AB (2019) Hepato-protective 254 effect of curcumin and silymarin against Eimeria stiedae in experimentally infected rabbits. Livst 255 Sci. 2019, 221, 33-38.

256 Agnoletti F, Lenarduzzi M, Ricci A, Marotta A. (1999) Isolation of Salmonella spp, from Italian 257 commercial rabbitries. CIHEAM-Options Méditerranéennes

258 Agrawal R and Hirpurkar SD (2016) prevalence of Salmonella spp. on exterior and interior of 259 fertile eggs from vaccinated breeding hens of different breeds. J Dairy Vet Anim Res 3(5): 00095

260 Albuquerque AH, Maciel WC, Souza Lopes E, Castro Teixeira RS, Salles RPR, Machado DN, 261 Bezerra WGA, Vasconcelos RH, Mendonça SV, Carbo CB (2014) Presence of Salmonella spp. in 262 Oneday- old Chicks from Hatcheries in the Metropolitan Region of Fortaleza, Brazil Acta Sci Vet 263 42: 12-22

264 Ashayerizadeh A, Dabiri N, Ashayerizadeh O, Mirzadeh KH, Roshanfekr H, Mamooee M 265 (2009) Effect of dietary antibiotic, probiotic and probiotic as growth promoters on growth 266 performance, carcass characteristics and haematological indices of broiler chickens. Pak. J. Biol. 267 Sci. 12: $52-57$

268 Arakawa A, Fukaton T, Baba E, McDougald LR, Bailey JS, Blankenship LC (1992) Influence of 269 coccidosis on colonisation in broiler chickens under floor pen conditions. Poultry Science71: $27059 \tilde{N} 63$

271 Brink D, Schroder G, Pauwels P (2006) "The effect of strategic and tactical cause-related 272 marketing on consumers' brand loyalty", Journal of Consumer Marketing 23(1): 15-25 
273 Borrelli L, Fioretti A, Ruggiero V, Santaniello A, Cringoli G, Ricci A, Barco L, Menna LF, 274 Dipineto L (2011) Salmonella Typhimurium DT104 in Farmed Rabbits. J Vet Med Sci 73: 385$275 \quad 387$

276 Camarda A, Pugliese N, Circella E, Caroli A, Legretto M, Pazzani C (2012) Salmonella Ser. 277 Typhimurium isolated from rabbit farms :characterization and epidemiological implications. 10th 278 World Rabbit Conger 1155-1158

279 CLSI/NCClS (2009) Performance Standards for Antimicrobial Disk Susceptibility Tests, 280 Approval Standard Tenth Edition and Performance Standards for Antimicrobial Susceptibility 281 Test, M02-A10 and M100-S20

282 Cruickshank H, Duguid JP, Marmon BP, Swain RHA (1975) Medical Microbiology. The practice 283 of Medical Microbiology, Vol. $150,12^{\text {th }}$ Ed. Churchill Livingstone, Edinburgh. London and New 284 York

285 Dalle Zotte A, Szendro Z (2011) The role of rabbit meat as functional food. Meat Sci 88: 319$286 \quad 331$

287 Donalson LM, McReynolds JL, Kim WK, Chalova VI, Woodward CL, Kubena LF, Nisbet DJ, 288 Ricke SC (2008) The influence of a fructooligosaccharide prebiotic combined with alfalfa molt 289 diets on the gastrointestinal tract fermentation, Salmonella enteritidis infection, and intestinal 290 shedding in laying hens. Poult Sci. 87(7):1253-62

291 El-Ashram SA, Aboelhadid S M, Abdel-Kafy E M, Hashem SA, Mahrous L N, Farghly EM, 292 Moawad UK, Kamel AA (2019) Prophylactic and Therapeutic E_cacy of Prebiotic 293 Supplementation against Intestinal Coccidiosis in Rabbits. Animals 9: 965; 294 doi:10.3390/ani9110965

295 El-Ashram S, Aboelhadid SM, Abdel-Kafy EM, Hashem SA, Mahrous LN, Farghly EM, Kamel 296 AA (2020) Investigation of Pre- and Post-Weaning Mortalities in Rabbits Bred in Egypt, with 297 Reference to Parasitic and Bacterial Causes. Animals, 10, 537; doi:10.3390/ani10030537 
298 European Union Commission (2005) Ban on antibiotics as growth promoters in animal feed

299 enters into effect. Regulation 1831/2003/ec on additives for use in animal nutrition, replacing

300 directive 700/524//333c on additives in feedstuffs, Brussels, 22 December

301 Ferket PR, Parks CW, Grimes JL. BENEFITS OF DIETARY ANTIBIOTIC AND

302 MANNANOLIGOSACCHARIDE SUPPLEMENTATION FOR POULTRY. Multi-State Poultry

303 Meeting May 14-16, 2002

304 Flickinger EA, Fahey GC (2002) Pet food and feed applications of inulin, oligofructose and other 305 oligosaccharide. Br J Nutr 87: 297 - 300

306 García A, Fox J G, Besser T E (2010) Zoonotic Enterohemorrhagic Escherichia coli: A One 307 Health Perspective ILAR Journal 51(3): 221-232, https://doi.org/10.1093/ilar.51.3.221

308 Gibson GR, Hutkins R, Sanders ME, Prescott SL, Reimer RA, Salminen SJ, Scott K, 309 Stanton C, Swanson KS, Cani PD, Verbeke K, Reid G. Expert consensus document: 310 The International Scientific Association for Probiotics and Prebiotics (ISAPP) 311 consensus statement on the definition and scope of prebiotics. Nat Rev 312 Gastroenterol Hepatol. 2017 Aug;14(8):491-502. doi: 10.1038/nrgastro.2017.75. 313 Epub 2017 Jun 14. PMID: 28611480.Gibson GR, Roberfroid MB (1995) Dietary modulation 314 of the human colonic microbiota: introducing the concept of prebiotics. J Nutr 125, 1401- 1412 315 Girgis G, Powell M, Youssef M, Graugnard DE, King WD, Dawson KA (2020) Effects of a 316 mannan-rich yeast cell wall-derived preparation on cecal concentrations and tissue prevalence of 317 Salmonella Enteritidis in layer chickens. PLoS One. 15(4):e0232088. 318 doi:10.1371/journal.pone.0232088

319 Hamed AM, Eid AAM, El-Bakrey RMM (2013) A review of rabbit diseases in Egypt. Wartazoa 32023 (4): 185-194

321 Holt JG, Krieg NR, Sneath PH, Staley JT, Williams ST (1994) Bergey's Manual of determinate 322 bacteriology, nineth Edition. Williams and Wilkins, Baltimore 
ISO 6579: (2002) International Organization for Standardization (2002). Horizontal method for

324 the detection of Salmonella spp. Microbiology of food and animal feeding stuff.

325 Jouany JP, Gobert J, Medina B (2008) Effect of live yeast culture supplementation on apparent

326 digestibility and rate of passage in horses fed a high fiber or high-starch diet. J Anim Sci 86: 339-

$327 \quad 347$

328 Kimse M (2009) Caracterisation de l'ecosystemececal et digestive du lupin:control e nutritionnel

329 et interaction avec la levure probiotique Saccharomyces cerevisiae. These de doctorat de

330 l'universite' de Toulouse

331 Kim MS, Lim TH, Jang JH, Lee DH, Kim BY, Kwon JH, Choi SW, Noh JY, Hong YH, Lee SB,

332 Yang SY, Lee HJ, Lee JB, Park SY, Choi IS, Song CS (2012) Prevalence and antimicrobial

333 resistance of Salmonella species isolated from chicken meats produced by different integrated

334 broiler operations in Korea. Poult Sci 91: 2370-5

335 Kritas SK, Morrison RB (2005) Evaluation of probiotics as asubstitute for antibiotics in a large

336 pig nursery. Vet. Rec. 2; 156 (14): 447-448

337 Kowalska Dorota, Bielański Paweł, Nosal Paweł, Kowal Jerzy (2012) Natural alternatives to

338 coccidiostats in rabbit nutrition. Ann Anim Sci 12 (4): 561-574

339 Kumar Y, Sharma A, Mani KA (2009) High level of resistance to nalidixic acid in Salmonella

340 enterica serovar Typhi in CentralIndia. J Infect Dev Ctries 3(6): 467-469

341 Lamas A, Fernandez-No IC, Miranda JM, Vazquez B, Cepeda A, Franco CM (2016) Prevalence,

342 molecular characterization and antimicrobial resistance of Salmonella serovars isolated from

343 northwestern Spanish broiler flocks (2011-2015). Poult Sci 95: 2097-105

344 Lee MD, Arp LH (1998) A laboratory manual for the isolation and identification of avian

345 pathogen Daviv E. Swayne, Chairman, John R. Glisson, Mark W.Jackwood, James E.Pearson,

346 Willie M. Reed. Editorial Board for the American Association of Avian Pathologists, 4th ed.,

347 Chapter 3, Colibacillosis. 14-16 
348 Lee GY, Jang HI, Hwang IG, Rhee MS (2009) Prevalence and classification of pathogenic

349 Escherichia coli isolated from fresh beef, poultry, and pork in Korea. Int J Food Microbiol 134

350 (3): 196-200

351 Lillehoj, H.S., Ruff M.D., 1987. Comparison of disease susceptibility and subclass-specific

352 antibody response in SC and FP chickens experimentally inoculated with E. tenella, E.

353 acervulina, or E. maxima. Avian Dis. 31, 112-119.

354 Makhol BM, Habreh N, Sakural K (2011) Antibiotic resistance of E.coli isolated from poultry in 355 Syria. Assiut Vet Med J 57 (128): 265-275

356 Michelland RJ, Combes S, Monteils V, (2010) Molecular analysis of the bacterial community in 357 digestive tract of rabbit. Anaerobe 16: 61-65

358 MICHAEL, Geovana Brenner; SIMONETI, Roselis; COSTA, Marisa da and CARDOSO, Marisa (2003) Comparison 359 of different selective enrichment steps to isolate Salmonella sp. from feces of finishing swine. Braz. J. 360 Microbiol. [online]. 2003, vol.34, n.2 [cited 2020-12-07], pp.138-142. Available from: ISSN 1678361 4405. https://doi.org/10.1590/S1517-83822003000200009.Micciche AC, Foley SL, Pavlidis HO, McIntyre 362 DR, Ricke SC (2018) A Review of Prebiotics Against Salmonella in Poultry: Current and Future 363 Potential for Microbiome Research Applications. Front Vet Sci 5:191 364 doi:10.3389/fvets.2018.00191.

365 Millman JM, Waits K, Grande H, Marks AR, Marks JC, Price LB, Hungate BA. (2013) 366 Prevalence of antibiotic-resistant E. coli in retail chicken: comparing conventional, 367 organic, kosher, and raised without antibiotics. F1000Res. 2013 Jul 11;2:155. doi: 368 10.12688/f1000research.2-155.v2. PMID: 24555073; PMCID: PMC3901448. Mitchell

369 SM, Ullman JL, Teel AL, Watts RJ, Frear C. 2013. The effects of the antibiotics ampicillin, 370 florfenicol, sulfamethazine, and tylosin on biogas production and their degradation efficiency 371 during anaerobic digestion. Bioresour. Technol. 149:244-52 
373 Nguyen RN, Taylor LS, Tauschek M, Robins-Browne RM (2006) Atypical 374 enteropathogenic Escherichia coli infection and prolonged diarrhea in children. Emerg Infect 375 Dis 12:597-603

376 Pakandl M (2009) "Coccidia of rabbit: A review," Folia Parasitol 56 (3): 153-166

377 Popoff M, Le Minor L (2001) Antigenic formulas of the Salmonella serovars, WHO 378 Collaborating Centre for Reference and Research on Salmonella. World Health Organ

379 Prescott JF (1978) Escherichia Coli and Diarrhoea in the Rabbit. Vet Pathol 15(2):237-48

380 Rashwan AA, Marai IFM (2000) Mortality in young rabbits: a review. World Rabbit Sci 8(3):

$381 \quad 111-124$

382 Saco M1, Pérez de Rozas A, Aloy N, González J, Rosell JM, Badiola JI (2012) Salmonellosis in 383 rabbits. Field and laboratory Results during 1999-2011. 10 th World Rabbit Congress 384 September 3 - 6, Sharm El- Sheikh -Egypt, 1165- 1168

385 Servin AL, Coconnier MH (2003) Adhesion of probiotic strains to the intestinal mucosa and 386 interaction with pathogens. Best Practice \& Research Clinic Gastroenterol17 (5): 741-754 387 Smith DL, Harris AD, Johnson JA, Silbergeld EK, Morris JG (2002) Proceedings of the National 388 Academy of Sciences, U.S.A. 99:6434-6439.

389 Spring P, Wenk C, Connolly A, Kiers A (2015) A review of 733 published trials on Bio-Mos ${ }^{\circledR}$, 390 a mannan oligosaccharide, and Actigen ${ }^{\circledR}$, a second generation mannose rich fraction, on farm 391 and companion animals. Journal of Applied Animal Nutrition, Vol. 3; e7; page 1 of 11 392

393 Szabóová R, Lauková A, Chrastinová l', Strompfová V, Monika SP, Plachá I, Vasilková Z, 394 Chrenková M, Faix S (2012) Benefficial effect of plant extracts in rabbit husbandry. Acta Vet 395 Brno 81: 245-250 
396 Swennes AG, Ellen MB, Nicola MAP, Carolyn MM, Alexis G, Peter B M, Keith MA, James GF

397 (2012) Enzootic Enteropathogenic Escherichia coli Infection in Laboratory Rabbits. J Clinic

398 Microbiol 50 (7): 2353-2358

399 Swennes AG, Buckley EM, Madden CM, Byrd CP, Donocoff RS, Rodriguez L, Parry N M A, 400 Fox JG (2014) Enteropathogenic Escherichia coli Prevalence in Laboratory Rabbits. Vet 401 Microbiol 163(3-4): 395-398

402 Taylor MA, Catchpole J, Marshall J, Marshall, RN, Hoeben D (2003) Histopathological 403 observations on the activity of diclazuril (Vecoxan) against the endogenous stages of Eimeria 404 crandallis in sheep. Vet Parasitol 116(4): 305-14

405 Timmerman HM, Mulder L, Everts H, van Espen DC, van der Wal E, Klaassen G, Rouwers SM, 406 Hartemink R, Rombouts FM, Beynen AC (2005) Health and growth of veal calves fed milk 407 replacers with or without probiotics. J Dairy Sci 88(6): 2154-2165

408 Tran K, Jethmalani Y, Jaiswal D, Green EM (2018) Set4 Is a Chromatin-Associated Protein, 409 Promotes Survival During Oxidative Stress, and Regulates Stress Response Genes in Yeast. J 410 Biol Chem 14; 293(37):14429-14443 doi: 10.1074/jbc.RA118.003078

411 Tzortzis G, Goulas AK, Gee JM, Gibson GR (2005) A novel galactooligosaccharide mixture 412 increases the bifidobacterial population numbers in a continuous in vitro fermentation system and 413 in the proximal colonic contents of pigs in vivo. J Nutr 135(7):1726-31

414 Walsh JL, Percival A, Turner PV. (2017) Efficacy of blunt force trauma, a novel mechanical 415 cervical dislocation device, and a non-penetrating captive bolt device for on-farm euthanasia of 416 pre-weaned kits, growers, and adult commercial meat rabbits. Animals (Basel) 2017;7:100.

417 World Health Organization. Communicable Diseases Cluster. (2000). Overcoming antimicrobial 418 resistance. https://apps.who.int/iris/handle/10665/66672

419 Yusrizal, Chen TC (2003) Effect of adding chicory fructans in feed on fecal and intestinal 420 microflora and excreta volatile ammonia. Int J Poult Sci 2: 188-194 
421 Zahraei T, Mahzouniehand M, Khaksar E (2010) Detection of Salmonella serovars in zoo and pet 422 reptiles, rabbits, and rodents in Iran by culture and PCR methods. Comp Clin Pathol 19:199-202. 423 doi: 10.1007/s00580-009-0841-8

424 Zhao Xiaonan, Jie Yang, Zijing Ju, Weishan Chang, Shuhong Sun (2018) Molecular

425 Characterization of Antimicrobial Resistance in Escherichia coli from Rabbit Farms in Tai'an, 426 China. BioMed Research International, Article ID 8607647, 7 pages.

427

428

429

430

431

432 


\section{Table $\mathbf{1}$ (on next page)}

The oocysts count per gram of feces (OPG) in experimental infected rabbits for eight days post infection 
Table 1.The oocysts count per gram of feces (OPG) in experimental infected rabbits for eight 2 days post infection.

\begin{tabular}{|c|c|c|c|c|c|}
\hline Group & $4^{\text {th }}$ day PI & $5^{\text {th }}$ day PI & 6th day PI & $7^{\text {th }}$ day PI & $8^{\text {th }}$ day PI \\
\hline $\begin{array}{l}\text { Negative Control } \\
\text { (NC) }\end{array}$ & $0.00 \pm 0.00$ & $0.00 \pm 0.00^{\mathrm{c}}$ & $0.00 \pm 0.00^{\mathrm{c}}$ & $0.00 \pm 0.00^{c}$ & $0.00 \pm 0.00^{\mathrm{c}}$ \\
\hline $\begin{array}{l}\text { Positive Control } \\
\text { (PC) }\end{array}$ & $0.00 \pm 0.00$ & $43333.33 \pm 4409.58^{\mathrm{a}}$ & $173666.67 \pm 3282.95^{\mathrm{a}}$ & $380000 \pm 6082.95^{\mathrm{a}}$ & $440666.67 \pm 2962.73^{a}$ \\
\hline $\begin{array}{c}\text { Prebiotic } \\
\text { supplemented (PS) }\end{array}$ & $0.00 \pm 0.00$ & $25166.67 \pm 2743.67^{b}$ & $107666.67 \pm 4333.33^{b}$ & $207000 \pm 4618.80^{\mathrm{b}}$ & $262000 \pm 2309.40^{\mathrm{b}}$ \\
\hline
\end{tabular}

Data are presented as the means for each group and standard error of the mean (Mean $\pm \mathrm{SE})$. ${ }^{\mathrm{a}, \mathrm{b}, \mathrm{c}}$ means within the 4

same column with different superscripts are significantly different at $(P \leq 0.05)$. 


\section{Table 2 (on next page)}

Prevalence of Enterobactericae infection in examined samples for each group after prebiotic supplementation as a prophylaxis for rabbit intestinal coccidiosis 
Table 2. Prevalence of Enterobactericae infection in examined samples for each group after

\begin{tabular}{|c|c|c|c|c|c|}
\hline \multirow[t]{2}{*}{ Group } & \multicolumn{2}{|c|}{ E. coli infection } & \multicolumn{2}{|c|}{ Salmonella infection } & \multirow{2}{*}{$\begin{array}{c}\text { Total } \\
\text { prevalence }\end{array}$} \\
\hline & $\begin{array}{c}\text { Examined } \\
\text { samples }\end{array}$ & Positive (\%) & $\begin{array}{l}\text { Examined } \\
\text { samples }\end{array}$ & $\begin{array}{c}\text { Positive } \\
(\%)\end{array}$ & \\
\hline $\begin{array}{c}\text { Non- } \\
\text { supplemented } \\
\text { non-infected } \\
\text { control group } \\
\text { (NC) }\end{array}$ & 15 & $3(20 \%)$ & 15 & $1(6.67 \%)$ & $4(8.89 \%)$ \\
\hline $\begin{array}{c}\text { Non- } \\
\text { supplemented } \\
\text { infected } \\
\text { control group } \\
\text { (PC) }\end{array}$ & 15 & $6(40 \%)$ & 15 & $3(20 \%)$ & $9(60 \%)$ \\
\hline $\begin{array}{c}\text { Prebiotic } \\
\text { supplemented } \\
\text { infected group } \\
\text { (PS) }\end{array}$ & 15 & $2(13.33)$ & 15 & 0 & $2(13.33 \%)$ \\
\hline Total & 45 & $11(24.44 \%)$ & 45 & $4(8.89 \%)$ & 15 \\
\hline
\end{tabular}




\section{Table 3 (on next page)}

Grouping of $E$. coli isolates recovered from different organs of prebiotic supplemented rabbits 
Table 3. Grouping of E. coli isolates recovered from different organs of prebiotic supplemented 1 rabbits

\begin{tabular}{cccc}
\hline $\begin{array}{c}\text { E. coli } \\
\text { serogroups }\end{array}$ & No. of isolates & $\%$ & Organs of isolation \\
\hline O78 & 3 & 27.27 & Jejunum and Ilium. \\
\hline O125 & 2 & 18.18 & Ilium. \\
\hline O152 & 3 & 27.27 & Jejunum and Ilium. \\
\hline O115 & 1 & 9.09 & Caecum. \\
\hline O168 & 2 & 18.18 & Caecum and Ilium. \\
\hline Total & 11 & 100 & \\
\hline
\end{tabular}


Table 4 (on next page)

Antimicrobial sensitivity of $E$.coli isolates in examined samples of prebiotic supplemented rabbits 
Table 4. Antimicrobial sensitivity of E.coli isolates in examined samples of prebiotic supplemented rabbits

\begin{tabular}{ccccccc}
\hline $\begin{array}{c}\text { Antimicrobial } \\
\text { agents }\end{array}$ & \multicolumn{2}{c}{ Resistance } & \multicolumn{2}{c}{ Intermediate } & \multicolumn{2}{c}{ Sensitive } \\
\cline { 2 - 6 } & NO & $\%$ & NO & $\%$ & NO & $\%$ \\
\hline Tetracycline & 9 & 81.81 & 2 & 18.18 & 0 & 0 \\
\hline Sulphamazole & 8 & 72.72 & 3 & 27.27 & 0 \\
\hline Naldixic acid & 9 & 81.81 & 2 & 18.18 & 0 \\
\hline Trimethoprim & 9 & 81.81 & 2 & 18.18 & 0 \\
\hline Gentamycin & 6 & 54.54 & 4 & 36.36 & 1 \\
\hline Levofloxacin & 8 & 72.72 & 3 & 27.27 & 0 \\
\hline Florfenicol & 11 & 100 & 0 & 0 & 0 \\
\hline Amoxicillin & 4 & 36.36 & 6 & 54.54 & 1 \\
\hline Flumequin & 9 & 81.81 & 1 & 9.09 & 1 \\
\hline Ciprofloxacine & 4 & 36.36 & 5 & 45.45 & 2 \\
\hline Amikacin & 1 & 9.09 & 4 & 36.36 & 6 \\
\hline Neomycin & 11 & 100 & 0 & 0 & 0 \\
\hline & & & & & \\
\hline
\end{tabular}




\section{Table 5 (on next page)}

Prevalence of Salmonella serovars isolated from the examined samples of prebiotic supplemented rabbits 
Table 5. Prevalence of Salmonella serovars isolated from the examined samples of prebiotic 1 supplemented rabbits

\begin{tabular}{ccccc}
\hline Salmonella serovars & No. of isolates & Group & $\begin{array}{l}\text { Organ of } \\
\text { isolation }\end{array}$ & Prevalence \% \\
\hline S.Macclesfield & 1 & PC & Caecum & $25 \%$ \\
\hline S.Canada & 1 & NC & Jujenum & $25 \%$ \\
\hline S.Kisangani & 2 & PC & Ilium & $50 \%$ \\
\hline
\end{tabular}




\section{Table 6(on next page)}

Antimicrobial sensitivity of Salmonella serovars from the examined samples of prebiotic supplemented rabbits 
Table 6. Antimicrobial sensitivity of Salmonella serovars from the examined samples of 1 prebiotic supplemented rabbits

\begin{tabular}{ccccccc}
\hline $\begin{array}{c}\text { Antimicrobial } \\
\text { agents }\end{array}$ & \multicolumn{2}{c}{ Resistance } & \multicolumn{2}{c}{ Intermediate } & \multicolumn{2}{c}{ Sensitive } \\
\cline { 2 - 7 } & NO & $\%$ & NO & $\%$ & NO & $\%$ \\
\hline Tetracycline & 2 & 50 & 2 & 50 & 0 & 0 \\
\hline Sulphamazole & 3 & 75 & 1 & 25 & 0 & 0 \\
\hline Naldixic acid & 2 & 50 & 2 & 50 & 0 & 0 \\
\hline Trimethoprim & 0 & 0 & 2 & 50 & 2 & 50 \\
\hline Gentamycin & 1 & 25 & 1 & 25 & 2 & 50 \\
\hline Levofloxacin & 0 & 0 & 1 & 25 & 3 & 75 \\
\hline Florfenicol & 2 & 50 & 2 & 50 & 0 & 0 \\
\hline Amoxicillin & 3 & 75 & 1 & 25 & 0 & 0 \\
\hline Flumequin & 3 & 75 & 1 & 25 & 0 & 0 \\
\hline Ciprofloxacine & 0 & 0 & 1 & 25 & 3 & 75 \\
\hline Amikacin & 1 & 25 & 1 & 25 & 2 & 50 \\
\hline Neomycin & 1 & 25 & 3 & 75 & 0 & 0 \\
\hline & & & & & & \\
\hline & & & & & 25 & 0 \\
\hline
\end{tabular}

